\title{
BLOOD PROFILES AND HISTO-MORPHOMETRIC ANALYSIS OF THE GASTROINTESTINAL TRACTS OF ROSS 308 BROILER AND INDIGENOUS VENDA CHICKENS FED THE SAME DIET
}

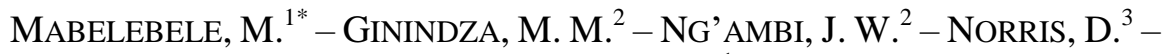 \\ MBAJIORGU, C. A. ${ }^{1}$ \\ ${ }^{I}$ Department of Agriculture and Animal Health, College of Agriculture and Environmental \\ Science, University of South Africa, Cnr Christiaan de Wet Rd \& Pioneer Ave 1724 Florida \\ Park, Roodepoort, Gauteng, South Africa \\ ${ }^{2}$ Department of Animal Science, School of Agricultural and Environmental Sciences, University \\ of Limpopo, Private Bag X1106, Sovenga, Polokwane, South Africa \\ ${ }^{3}$ Department of Research, Development and Innovation, Botswana International University of \\ Science and Technology, Private Bag 16, Palapye, Botswana \\ *Corresponding author \\ e-mail:mabelebelem@gmail.com \\ (Received $28^{\text {th }}$ Feb 2017; accepted $20^{\text {th }}$ Jul 2017)
}

\begin{abstract}
The aim of this study was to assess the blood parameters and gut histology of broiler and indigenous chickens at different ages. A total of 120 Ross 308 broiler and Venda chickens were assigned in a complete randomized design to assess blood profiles and gut histomorphology in order to determine the immunity and digestive ability of the two breeds. Blood profiles and gut histology of two breeds at ages 42 and 90 days were determined. A measuring tape and RADWAG digital scale (Model PS 750/C/2) were used to measure the lengths and weights, respectively. At 42 days, platelets and serum creatinine were higher $(\mathrm{P}<0.05)$ for Ross 308 broiler than Venda chickens. Total protein was higher $(\mathrm{P}<0.05)$ in Venda than Ross 308 broiler chickens. The blood parameters measured at 90 days were higher $(\mathrm{P}<0.05)$ in Ross 308 broiler. Platelets were higher $(\mathrm{P}<0.05)$ in Venda than in Ross 308 broiler chickens. Weights and lengths of the gut were higher $(\mathrm{P}<0.05)$ in Ross 308 broiler than Venda chickens at both 42 and 90 days. Jejunum villus height was higher $(\mathrm{P}<0.05)$ in Ross 308 broiler than in Venda chickens aged 42 days. Crypt depth was higher $(\mathrm{P}<0.05)$ in the duodenum and ileum of Ross 308 broiler than in Venda chickens. The villus height/crypt depth ratios were higher $(\mathrm{P}<0.05)$ in Venda than Ross 308 broiler chickens at both 42 days. Age and breed affects blood profiles of broiler and indigenous chickens. The histomorphology of Ross 308 broiler was superior which reflects better absorption capabilities compared to Venda chickens.
\end{abstract}

Keywords: haematology, weights, lengths, villi height, crypt depth

\section{Introduction}

Chickens contribute a lot to social and economic well-being of most rural households of South Africa. The feed intake, digestibility, growth rate and overall productivity of broiler and indigenous chickens vary (Pauwels et al., 2015; Rondelli et al., 2003). Haematological and blood parameters of chickens are reliable indicators of their health status and productivity (Abdi-Hachesoo et al., 2011). Indigenous chickens which are mainly abundant in rural areas are known to be tolerant and resistant to diseases than their counterpart Ross 308 broiler chickens (Abdi-Hachesoo et al., 2013). It is, therefore, important to understand and determine the haematological indices of indigenous chickens in order to better interpret their health status and immune system capability to tolerate poultry 
diseases. The gastrointestinal tract (GIT) of the chicken and its gut state and condition are accountable for nutrient digestion, metabolism and absorption (Mabelebele et al., 2014). The GIT of fast growing Ross 308 broiler chickens develop and mature faster than those of the slow growing indigenous chickens (Jamroz, 2005). Ross 308 broiler chickens have been selected for high feed conversion ratio and growth rate. This has resulted in changes in the anatomy and function of the digestive system (Krás et al., 2013). The length and weight of the small intestines vary between the different species of birds (Hassouna et al., 2001).

Histologically, villus height and mucosa thickness are normally used as a good index for understanding the intestinal status which is directly linked to the absorptive functions (Incharoen, 2013). Morphology and histology of the gastrointestinal tract of Ross 308 broiler chickens were described and studied previously by Aitken (1958), Calhoun (1954) and Hassouna (2001). However, in more recent studies by Mabelebele et al. (2014), the digestive organ weights and lengths of Ross 308 broiler and indigenous Venda chickens at 90 days of age were compared. These authors observed that although broiler chickens at 90 days of age had heavier and longer digestive organs however, Venda chickens had lower gizzard $\mathrm{pH}$, which might be related with better fibre digestion. As such, not much information on the blood profiles, morphology and histological differences between Ross 308 broiler and indigenous Venda chickens is available. Therefore, the objective of this study was to determine the differences between the blood profiles, morphometric and histological analyses of Ross 308 broiler and indigenous Venda chickens raised under the same conditions and fed a similar diet.

\section{Materials and methods}

\section{Study site and experimental design}

This study was conducted at the University of Limpopo Animal Unit. The study commenced with 60 Ross 308 broiler and 60 Venda chickens aged 1 day. Ross 308 broilers chickens were acquired from Lufafa hatchery, Tzaneen, South Africa while indigenous Venda chickens were obtained from the University of Limpopo hatchery. The chickens were kept for a period of 90 days on a commercial diet (Table 1). Feed and water were provided ad libitum and except for the first day when 24 hours of light was provided, 18 hours of lighting and 6 hours of darkness in every 24-hour period was maintained throughout the trial period. Chickens were housed in pens, assigned to a complete randomized design with each breed replicated five times with twelve birds per replicate. All managements of the birds were carried out with the strict accordance of the rules and regulations of the University of Limpopo Animal Ethics Committee with the following ethics approval number (TREC/12/2014:IR).

Table 1. Ingredients and nutrient contents of diets fed at 0-42 and 43-90 days.

\begin{tabular}{c|c|c}
\hline Ingredients (g/kg) & $\mathbf{0 - 4 2}$ days & $\mathbf{4 3 - 9 0}$ days \\
\hline Yellow maize & 672.53 & 738.43 \\
SBM & 156.21 & 140.97 \\
Canola (solvent-extracted) & 50.00 & 10.00 \\
Meat meal & 87.31 & 79.39 \\
Canola Oil & 12.75 & 15.43 \\
\hline
\end{tabular}




\begin{tabular}{c|c|c}
\hline Limestone & 2.36 & 2.46 \\
Dical Phos 18P/21Ca & 0.01 & 0.01 \\
Salt & 0.597 & 0.72 \\
Na bicarb & 1.82 & 1.89 \\
Vitamin/mineral premix ${ }^{\dagger}$ & 2.00 & 2.00 \\
Choline Cl 70\% & 1.28 & 1.16 \\
L-lysine HCl 78.4 & 4.04 & 3.81 \\
DL-methionine & 1.81 & 1.68 \\
L-threonine & 1.98 & 1.68 \\
Chemical composition (g/kg) & 12.97 & 13.39 \\
Metabolisable energy (MJ/kg) & 215.0 & 195.0 \\
Crude protein & 24.47 & 22.2 \\
Crude fiber & 45.5 & 47.9 \\
Crude fat & 11.1 & 9.84 \\
Digestible arginine & 11.5 & 10.2 \\
Digestible lysine & 4.7 & 4.3 \\
Digestible methionine & 7.0 & 6.3 \\
Digestible methionine + cysteine & 9.0 & 7.4 \\
Digestible leucine & 1.7 & 1.5 \\
Digestible tryptophan & 8.7 & 7.8 \\
Calcium & 4.35 & 3.9 \\
Available phosphorus & 2.3 & 6.6 \\
Potassium & 1.6 & 2.3 \\
Chloride & 1.6 & 1.6 \\
Sodium & 1600 & 1500 \\
Choline (mg/kg) &
\end{tabular}

$\dagger$ The active ingredients contained in the vitamin-mineral premix were as follows (per kg of diet): vitamin A - $12000 \mathrm{IU}$, vitamin D3 - $3500 \mathrm{IU}$, vitamin $\mathrm{E}-30.0 \mathrm{mg}$, vitamin $\mathrm{K} 3-2.0 \mathrm{mg}$, thiamine -2 $\mathrm{mg}$, riboflavin $-6 \mathrm{mg}$, pyridoxine $-5 \mathrm{mg}$, vitamin $\mathrm{B} 12-0.02 \mathrm{mg}$, niacin $-50 \mathrm{mg}$, pantothenate -12 $\mathrm{mg}$, biotin $0 Æ 01 \mathrm{mg}$, folic acid $-2 \mathrm{mg}, \mathrm{Fe}-60 \mathrm{mg}, \mathrm{Zn}-60 \mathrm{mg}, \mathrm{Mn}-80 \mathrm{mg}, \mathrm{Cu}-8 \mathrm{mg}, \mathrm{Se}-0 Æ 1 \mathrm{mg}$, Mo $-1 \mathrm{mg}, \mathrm{Co}-0 Æ 3 \mathrm{mg}, \mathrm{I}-1$

\section{Haematological values}

Two chickens per replicate were selected for slaughter at 42 and 90 days of age. Before slaughter, $3 \mathrm{ml}$ of blood samples from both Ross 308 broiler and Venda chickens were collected from a jugular vein into two test tubes per bird, one with ethylenediaminetetraacetic acid (EDTA) as an anticoagulant and the other without EDTA. The blood collection tubes were kept in ice to avoid denaturing of protein, and plasma was stored at $-20{ }^{\circ} \mathrm{C}$ until further analysis. Blood samples were analysed within 2 hours of collection for haematocrit (HCT), red blood cell (RBC), white blood cell (WBC) and haemoglobin (HBG) according to the methods of Dein (1984). Haemoglobin amount was measured using the Beckman Coulter ACT diff Haematology Analyzer (Beckman-Coulter, USA). Platelet counts were also measured. The HCT was measured as micro haematocrit with $75 \times 16 \mathrm{~mm}$ capillary tubes and centrifuged at $2500 \mathrm{rpm}$ for 5 minutes. Mean corpuscular volume (MCV), Mean corpuscular haemoglobin $(\mathrm{MCH})$ and Mean corpuscular haemoglobin concentration (MCHC) were calculated according to Ritchie et al. (1994). Serum parameters analysed included total protein, albumen, glucose, cholesterol, triglycerides, calcium, phosphorus, sodium and potassium (Aravind et al., 2003). 


\section{Morphology of the gastrointestinal tracts}

In order to evaluate organ weights and intestinal morphometrics of the chickens at 42 and 90 days of age, the gizzard, proventriculus, small intestines and the large intestines, including the caeca, were collected and weighed immediately at both 42 and 90 days. A measuring tape and RADWAG digital scale (Model PS 750/C/2) were used to measure the lengths and weights, respectively. The gizzard was weighed after the contents were removed and cleaned. After removal of the contents, the small and large intestines were cut in segments, cleaned, weighed and measured. The small intestines were measured from the site where the duodenum emerges from the gizzard and the beginning of the caeca, and the large intestine length included the length of the colon and the rectum. Chickens were weighed before slaughter.

\section{Digestibility and Histological analysis}

Nutrient digestibility at 42 days of age was determined according to the methods of McDonalds et al (1992). At the ages 42 and 90 days, 2 birds per pen were sacrificed by cervical dislocation. The whole small intestine was removed immediately and immersed in $10 \%$ buffered formalin. Three small intestine segments measuring approximately 3.0 $\mathrm{cm}$ of the duodenum (from the gizzard to pancreatic and bile duct), jejunum (from the bile duct to Meckel's diverticulum) and ileum (from the Meckel's diverticulum to ileocaecalcolonic junction) were cut according to Samanya and Yamauchi (2002) for each chicken at ages 42 and 90 days. The samples were washed in phosphate buffer solution at $0.1 \mathrm{M}(\mathrm{pH} 7.4)$ and fixed in Bouin solution for three days. The samples were then trimmed to eliminate the torn edges, and remained for further 24 hours in the fixing solution. The samples were washed in ethanol at $70 \%$ to remove the fixing solutions, dehydrated in graded series of alcohol and cleaned in xylol. Four semi-serial sections with 7-cm thickness were placed in each slide. The slides were dyed using the method of the periodic acid of Schiff (PAS). Using an image capture and analysis system (Image J, 1.47r), villi height and crypt depths were measured in duodenum, jejunum and ileum sections were measured. Villus height was measured from the basal region, which starts at the higher portion of the crypt, until villus tip, whereas crypt depth was measure from the base up to the crypt-villi transition region (Carrijo et al., 2005).

\section{Statistical analysis}

Data on haematology, morphology and histology of the GIT of both Ross 308 broiler and Venda chickens were analysed using the General Linear Model (GML) procedure of the statistical analysis of variance (SAS, 2008). Differences were considered significant at $\mathrm{P}<0.05$.

\section{Results}

\section{Haematological and biochemical parameters of Ross 308 broiler and Venda chickens aged 42 and 90 days}

The results of the blood profiles of Ross 308 broiler and Venda chickens aged 42 days are presented in Table 2. No significant $(\mathrm{P}>0.05)$ differences were observed on the complete blood count and biochemical parameters between the chicken breeds except for platelets and serum creatinine. The platelets were higher $(\mathrm{P}<0.05)$ in Ross 308 broiler than in Venda chickens. Serum creatinine at 42 days of age was higher $(\mathrm{P}<0.05)$ 
for Ross 308 broiler than Venda chickens. However, the total protein of Venda chickens at 42 days of age were higher $(\mathrm{P}<0.05)$ than those of Ross 308 broiler chickens. The results of the blood profiles of Ross 308 broiler and Venda chickens aged 90 days are presented in Table 3. The WBC, RBC, HGB, HCT and MCV were lower $(\mathrm{P}<0.05)$ in Venda than Ross 308 broiler chickens. However, the platelets were lower $(\mathrm{P}<0.05)$ in Ross 308 broiler than Venda chickens. No significant differences $(\mathrm{P}>0.05)$ in $\mathrm{MCH}$, MCHC, RDW were observed between Ross 308 broiler and Venda chickens aged 90 days. Serum calcium, creatinine, cholesterol and albumen were higher $(\mathrm{P}<0.05)$ in broiler than indigenous chickens. However, sodium, potassium, phosphorus, glucose and total protein were similar in Ross 308 broiler and Venda chickens. Venda chickens had higher $(\mathrm{P}<0.05)$ serum triglycerides than those in Ross 308 broiler chickens.

Table 2. The haemato-biochemical profiles of Ross 308 broiler and Venda chickens aged 42 days

\begin{tabular}{c|c|c|c}
\hline Parameters & $\begin{array}{c}\text { Ross 308 } \\
\text { broiler }\end{array}$ & Venda chickens & SEM \\
\hline WBC $\left(\times 10^{3}\right.$ cell/ $\left.\mu \mathrm{L}\right)$ & 90 & 88 & 3.32 \\
RBC $\left(\times 10^{6}\right.$ cell/ $\left.\mu \mathrm{L}\right)$ & 2 & 2 & 0.27 \\
Haemoglobin $(\mathrm{g} / \mathrm{dL})$ & 10 & 13 & 1.26 \\
Haematocrit $(\mathrm{L} / \mathrm{L})$ & 32 & 39 & 3.95 \\
MCV $(\mathrm{fL})$ & 134 & 137 & 4.98 \\
MCH $(\mathrm{pg})$ & 45 & 45. & 0.56 \\
MCHC $(\mathrm{g} / \mathrm{dL})$ & 33 & 32. & 0.34 \\
RDW \% & 7 & 7. & 0.10 \\
Platelets & $59^{\mathrm{a}}$ & $24^{\mathrm{b}}$ & 10.13 \\
Sodium $(\mathrm{mmol} / \mathrm{L})$ & 162 & 156 & 5.21 \\
Potassium $(\mathrm{mmol} / \mathrm{L})$ & 10 & 10 & 0.64 \\
Calcium $(\mathrm{mmol} / \mathrm{L})$ & 2 & 2 & 0.07 \\
Magnesium $(\mathrm{mmol} / \mathrm{L})$ & 1 & 0.9 & 0.24 \\
Glucose $(\mathrm{mmol} / \mathrm{L})$ & 17 & 14 & 2.15 \\
Creatinine $(\mu \mathrm{mol} / \mathrm{L})$ & $17^{\mathrm{a}}$ & $9^{\mathrm{b}}$ & 5.05 \\
Cholesterol $(\mathrm{mmol} / \mathrm{L})$ & 3 & 4 & 0.66 \\
Triglyceride $(\mathrm{mmol} / \mathrm{L})$ & 0.3 & 0.3 & 0.16 \\
Phosphorus $(\mathrm{mmol} / \mathrm{L})$ & 6 & 7 & 0.64 \\
Albumen $(\mathrm{g} / \mathrm{L})$ & 3 & 2 & 3.20 \\
Total protein $(\mathrm{g} / \mathrm{L})$ & $20^{\mathrm{b}}$ & $25^{\mathrm{a}}$ & 0.15 \\
\hline
\end{tabular}

SEM: Standard error of the mean

${ }^{\mathrm{a}, \mathrm{b}}$ Means within the same row with different letters are significantly different $(\mathrm{P}<0.05)$

Table 3. The haemato-biochemical profiles of Ross 308 broiler and Venda chickens aged 90 days

\begin{tabular}{c|c|c|c}
\hline Parameters & $\begin{array}{c}\text { Ross 308 } \\
\text { broiler }\end{array}$ & Venda chickens & SEM \\
\hline WBC $\left(\times 10^{3}\right.$ cell/ $\left.\mu \mathrm{L}\right)$ & $734^{\mathrm{a}}$ & $662.6^{\mathrm{b}}$ & 18.97 \\
RBC $\left(\times 10^{6}\right.$ cell/ $\left.\mu \mathrm{L}\right)$ & $2^{\mathrm{a}}$ & $1.8^{\mathrm{b}}$ & 0.15 \\
Haemoglobin $(\mathrm{g} / \mathrm{dL})$ & $10^{\mathrm{b}}$ & $12.6^{\mathrm{a}}$ & 0.66 \\
Haematocrit $(\mathrm{L} / \mathrm{L})$ & $0.2^{\mathrm{a}}$ & $0.2^{\mathrm{b}}$ & 0.01 \\
MCV ( fL) & $112^{\mathrm{a}}$ & $101.3^{\mathrm{b}}$ & 4.10 \\
MCH (pg) & 53 & 52.9 & 2.75 \\
MCHC (g/dL) & 47 & 46.8 & 3.11 \\
RDW \% & 18 & 19.2 & 1.05 \\
Platelets & $12^{\mathrm{b}}$ & $14.4^{\mathrm{a}}$ & 3.29 \\
\hline
\end{tabular}




\begin{tabular}{c|c|c|c}
\hline Sodium $(\mathrm{mmol} / \mathrm{L})$ & 157 & 150.0 & 2.66 \\
Potassium $(\mathrm{mmol} / \mathrm{L})$ & 11 & 10.3 & 0.65 \\
Calcium $(\mathrm{mmol} / \mathrm{L})$ & $2^{\mathrm{a}}$ & $2.5^{\mathrm{b}}$ & 0.02 \\
Glucose $(\mathrm{mmol} / \mathrm{L})$ & 15 & 15.6 & 0.20 \\
Creatinine $(\mu \mathrm{mol} / \mathrm{L})$ & $10^{\mathrm{a}}$ & $8.4^{\mathrm{b}}$ & 0.76 \\
Cholesterol $(\mathrm{mmol} / \mathrm{L})$ & $4^{\mathrm{a}}$ & $3.3^{\mathrm{b}}$ & 0.12 \\
Triglyceride $(\mathrm{mmol} / \mathrm{L})$ & $0.1^{\mathrm{b}}$ & $0.3^{\mathrm{a}}$ & 0.03 \\
Phosphorus $(\mathrm{mmol} / \mathrm{L})$ & 2 & 2 & 0.05 \\
K8Albumen $(\mathrm{g} / \mathrm{L})$ & $10^{\mathrm{a}}$ & $8^{\mathrm{b}}$ & 0.23 \\
Total protein $(\mathrm{g} / \mathrm{L})$ & 42 & 38 & 1.81 \\
\hline
\end{tabular}

SEM: Standard error of the mean

${ }^{\mathrm{a}, \mathrm{b}}$ Means within the same row with different letters are significantly different $(\mathrm{P}<0.05)$

Tables 4 and 5 show the live and carcass weights and gastrointestinal weights of Ross 308 broiler and Venda chickens aged 42 and 90 days. The live and carcass weights were heavier $(\mathrm{P}<0.05)$ for Ross 308 broiler than Venda chickens at both ages. The GIT weights of Ross 308 broiler were heavier $(\mathrm{P}<0.05)$ than those of the Venda chickens at both ages. The crop, proventriculus and gizzards were heavier $(\mathrm{P}<0.05)$ in Ross 308 broiler than in Venda chickens at both ages. Heavier weights $(\mathrm{P}<0.05)$ for small intestines, duodenum, jejunum, ileum, large intestines and the caeca were obtained in Ross 308 broiler than Venda chickens at both ages.

Table 4. The gastrointestinal tract weights ( $g$ ) of Ross 308 broiler and Venda chickens aged 42 days

\begin{tabular}{c|c|c|c}
\hline Parameters & Ross 308 broiler & Venda chickens & SEM \\
\hline Live-weight & $1443^{\mathrm{a}}$ & $520^{\mathrm{b}}$ & 489.91 \\
Carcass weight & $1004^{\mathrm{a}}$ & $309^{\mathrm{b}}$ & 369.55 \\
GIT & $198^{\mathrm{a}}$ & $89^{\mathrm{b}}$ & 60.39 \\
Crop & $12^{\mathrm{a}}$ & $4^{\mathrm{b}}$ & 5.39 \\
Proventriculus & $7^{\mathrm{a}}$ & $3^{\mathrm{b}}$ & 2.17 \\
Gizzard & $38^{\mathrm{a}}$ & $15^{\mathrm{b}}$ & 12.29 \\
Small intestine & $50^{\mathrm{a}}$ & $20^{\mathrm{b}}$ & 16.38 \\
Duodenum & $30^{\mathrm{a}}$ & $12^{\mathrm{b}}$ & 9.78 \\
Jejunum & $9^{\mathrm{a}}$ & $4^{\mathrm{b}}$ & 3.07 \\
Ileum & $7^{\mathrm{a}}$ & $3^{\mathrm{b}}$ & 3.73 \\
Large intestine & $8^{\mathrm{a}}$ & $4^{\mathrm{b}}$ & 2.28 \\
Caeca* & $4^{\mathrm{a}}$ & $2^{\mathrm{b}}$ & 2.19 \\
\hline
\end{tabular}

* An average value of each caeca pair

SEM: Standard error of the mean

${ }_{\mathrm{a}, \mathrm{b}}$ Means within the same row with different letters are significantly different $(\mathrm{P}<0.05)$

Table 5. The gastrointestinal tract weights ( $g$ ) of Ross 308 broiler and Venda chickens aged 90 days

\begin{tabular}{c|c|c|c}
\hline Parameters & Ross 308 broiler & Venda chickens & SEM \\
\hline Live-weight & $2861^{\mathrm{a}}$ & $1339^{\mathrm{b}}$ & 102.47 \\
Carcass weight & $2105^{\mathrm{a}}$ & $830^{\mathrm{b}}$ & 82.54 \\
GIT & $200^{\mathrm{a}}$ & $120^{\mathrm{b}}$ & 9.41 \\
Crop & $16^{\mathrm{a}}$ & $8^{\mathrm{b}}$ & 1.13 \\
Proventriculus & $11^{\mathrm{a}}$ & $7^{\mathrm{b}}$ & 0.45 \\
Gizzard & $53^{\mathrm{a}}$ & $36^{\mathrm{b}}$ & 2.65 \\
Small intestine & $78^{\mathrm{a}}$ & $47^{\mathrm{b}}$ & 7.27 \\
\hline
\end{tabular}




\begin{tabular}{c|c|c|c}
\hline Duodenum & $23^{\mathrm{a}}$ & $10^{\mathrm{b}}$ & 4.66 \\
Jejunum & $25^{\mathrm{a}}$ & $14^{\mathrm{b}}$ & 1.71 \\
Ileum & $26^{\mathrm{a}}$ & $21^{\mathrm{b}}$ & 2.18 \\
Large intestine & $32^{\mathrm{a}}$ & $12^{\mathrm{b}}$ & 0.56 \\
Caeca* & $7^{\mathrm{b}}$ & $10^{\mathrm{a}}$ & 2.41 \\
\hline
\end{tabular}

* An average value of each caeca pair

SEM: Standard error of the mean

${ }_{\mathrm{k} 8 \mathrm{a}, \mathrm{b}}$ Means within the same row with different letters are significantly different $(\mathrm{P}<0.05)$

The lengths of the gastrointestinal tract are presented in Tables 6 and 7. A similar trend observed for GIT weights was also observed for lengths with the entire tract being longer $(\mathrm{P}<0.05)$ for Ross 308 broiler than Venda chickens at 42 days of age. The small intestines, duodenum, ileum, large intestines and the caeca were shorter $(\mathrm{P}<0.05)$ for Venda than Ross 308 broiler chickens. At 90 days of age, the gastrointestinal lengths of the Venda chickens followed a similar tendency as their weights. The entire GIT length, small intestines and its segments, the large intestines and caeca were longer $(\mathrm{P}<0.05)$ for Ross 308 broiler than Venda chickens.

Table 6. The gastrointestinal tract lengths ( $\mathrm{cm}$ ) of Ross 308 broiler and Venda chickens aged 42 days

\begin{tabular}{c|c|c|c}
\hline Parameters & Ross 308 broiler & Venda chickens & SEM \\
\hline GIT & $202^{\mathrm{a}}$ & $124^{\mathrm{b}}$ & 42.42 \\
Small intestine & $147^{\mathrm{a}}$ & $98^{\mathrm{b}}$ & 29.49 \\
Duodenum & $95^{\mathrm{a}}$ & $53^{\mathrm{b}}$ & 22.80 \\
Jejunum & $39^{\mathrm{a}}$ & $23^{\mathrm{b}}$ & 7.82 \\
Ileum & $27^{\mathrm{a}}$ & $19^{\mathrm{b}}$ & 10.39 \\
Large intestine & $13^{\mathrm{a}}$ & $11^{\mathrm{b}}$ & 3.55 \\
Caeca* & $17^{\mathrm{a}}$ & $9^{\mathrm{b}}$ & 2.84 \\
\hline
\end{tabular}

* An average value of each caeca pair

SEM: Standard error of the mean

${ }^{\mathrm{a}, \mathrm{b}}$ Means within the same row with different letters are significantly different $(\mathrm{P}<0.05)$

Table 7. The gastrointestinal tract lengths (cm) of Ross 308 broiler and Venda chickens aged 90 days

\begin{tabular}{c|c|c|c}
\hline Parameters & Ross 308 broiler & Venda chickens & SEM \\
\cline { 2 - 3 } GIT & $208^{\mathrm{a}}$ & $138^{\mathrm{b}}$ & 8.96 \\
Small intestine & $179^{\mathrm{a}}$ & $114^{\mathrm{b}}$ & 8.86 \\
Duodenum & $34^{\mathrm{a}}$ & $22^{\mathrm{b}}$ & 1.92 \\
Jejunum & $64^{\mathrm{a}}$ & $39^{\mathrm{b}}$ & 2.27 \\
Ileum & $89^{\mathrm{a}}$ & $57^{\mathrm{b}}$ & 2.67 \\
Large intestine & $39^{\mathrm{a}}$ & $17^{\mathrm{b}}$ & 0.53 \\
Caeca* $^{\mathrm{b}}$ & $22^{\mathrm{a}}$ & $11^{\mathrm{b}}$ & 4.08 \\
\hline
\end{tabular}

* An average value of each caeca pair

SEM: Standard error of the mean

${ }^{\mathrm{a}, \mathrm{b}}$ Means within the same row with different letters are significantly different $(\mathrm{P}<0.05)$

The results of the villus height, crypt depth and villus/crypt depth ratio of small intestine segments between Ross 308 broiler and indigenous Venda chickens are presented in Tables 8 and 9. Similar villus heights $(\mathrm{P}>0.05)$ were observed on 
duodenum and ileum of Ross 308 broiler and Venda chickens aged 42 days. However, the jejunal villus height of Ross 308 broiler were higher $(\mathrm{P}<0.05)$ than those of Venda chickens aged 42 days. Duodenum and ileum crypt depths of Ross 308 broiler were higher $(\mathrm{P}<0.05)$ than those of Venda chickens aged 42 days. Similar $(\mathrm{P}>0.05)$ jejunum crypt depths were observed between Ross 308 broiler and Venda chickens. Venda chickens exhibited higher $(\mathrm{P}<0.05)$ villus/crypt depth ratios in all segments of the small intestines than Ross 308 broiler chickens at 42 days of age. Villus heights of the duodenum, jejunum and ileum were similar $(\mathrm{P}>0.05)$ between Ross 308 broiler and Venda chickens at 90 days. Crypt depths of the duodenum and ileum were higher in Ross 308 broiler chickens than in Venda chickens. However, no differences $(\mathrm{P}>0.05)$ in jejunal crypt depths were observed between the two breeds. Venda chickens had higher $(\mathrm{P}<0.05)$ ileum villus/crypt depth ratio than Ross 308 broiler chickens at ages 90days. No differences $(\mathrm{P}>0.05)$ were recorded on duodenum and jejunum villus/crypt depth ratios of Ross 308 broiler and Venda chickens aged 90 days. The results of nutrient digestibility of a grower diet fed to Ross 308 broiler and Venda chickens are presented in Table 10. Ross 308 broiler chickens showed higher $(\mathrm{P}<0.05)$ dry matter and crude protein digestibility, metabolisable energy and $\mathrm{N}$ retention than in Venda chickens.

Table 8. Histological measurements of duodenal, jejunal and ileal wall of Ross 308 broilers and Venda chickens aged 42 days

\begin{tabular}{c|c|c|c|c|c|c|c|c|c}
\hline & \multicolumn{2}{|c|}{ Duodenum } & & \multicolumn{2}{c|}{ Jejunum } & & \multicolumn{2}{c|}{ Ileum } & \\
\cline { 2 - 9 } Parameters & $\begin{array}{c}\text { Ross } \\
\mathbf{3 0 8} \\
\text { broiler }\end{array}$ & $\begin{array}{c}\text { Venda } \\
\text { chickens }\end{array}$ & SEM & $\begin{array}{c}\text { Ross } \\
\mathbf{3 0 8} \\
\text { broiler }\end{array}$ & $\begin{array}{c}\text { Venda } \\
\text { chickens }\end{array}$ & SEM & $\begin{array}{c}\text { Ross } \\
\text { 308 } \\
\text { broiler }\end{array}$ & $\begin{array}{c}\text { Venda } \\
\text { chickens }\end{array}$ & SEM \\
\hline $\begin{array}{c}\text { Villus height } \\
(\mathrm{mm})\end{array}$ & 758 & 783 & 21.4 & $720^{\mathrm{a}}$ & $624^{\mathrm{b}}$ & 22.43 & 617 & 665 & 21.07 \\
$\begin{array}{c}\text { Crypt depth } \\
(\mathrm{mm})\end{array}$ & $187^{\mathrm{a}}$ & $130^{\mathrm{b}}$ & 9.80 & 173 & 166 & 38.17 & $145^{\mathrm{a}}$ & $104^{\mathrm{b}}$ & 4.64 \\
$\begin{array}{c}\text { Villus/Crypt } \\
\text { ratio }\end{array}$ & $4^{\mathrm{b}}$ & $6^{\mathrm{a}}$ & 0.269 & $3^{\mathrm{b}}$ & $6^{\mathrm{a}}$ & 0.42 & $4^{\mathrm{b}}$ & $6^{\mathrm{a}}$ & 0.31 \\
\hline
\end{tabular}

SEM: Standard error of the mean

${ }^{a, b}$ Means within the same column with different letters are significantly different $(\mathrm{P}<0.05)$

Table 9. Histological measurements of duodenal, jejunal and ileal wall of Ross 308 broilers and Venda chickens aged 90 days

\begin{tabular}{c|c|c|c|c|c|c|c|c|c}
\hline & \multicolumn{2}{|c|}{ Duodenum } & & \multicolumn{2}{c|}{ Jejunum } & & \multicolumn{2}{c}{ Ileum } & \\
\cline { 2 - 9 } Parameters & $\begin{array}{c}\text { Ross } \\
\mathbf{3 0 8} \\
\text { broiler }\end{array}$ & $\begin{array}{c}\text { Venda } \\
\text { chickens }\end{array}$ & SEM & $\begin{array}{c}\text { Ross } \\
\mathbf{3 0 8} \\
\text { broiler }\end{array}$ & $\begin{array}{c}\text { Venda } \\
\text { chickens }\end{array}$ & SEM & $\begin{array}{c}\text { Ross } \\
\text { 308 } \\
\text { broiler }\end{array}$ & $\begin{array}{c}\text { Venda } \\
\text { chickens }\end{array}$ & SEM \\
\hline $\begin{array}{c}\text { Villus height } \\
\text { (mm) }\end{array}$ & 1266 & 1259. & 47.13 & 1146 & 1153 & 50.40 & 809 & 846 & 41.58 \\
$\begin{array}{c}\text { Crypt depth } \\
\text { (mm) }\end{array}$ & $339^{\mathrm{a}}$ & $275^{\mathrm{b}}$ & 11.54 & 302 & 253 & 24.19 & $319^{\mathrm{a}}$ & $219^{\mathrm{b}}$ & 35.19 \\
$\begin{array}{c}\text { Villus/Crypt } \\
\text { ratio }\end{array}$ & 3 & 4.1 & 0.28 & 4 & 4 & 0.35 & $2^{\mathrm{a}}$ & $4 .^{\mathrm{b}}$ & 0.30 \\
\hline
\end{tabular}

SEM: Standard error of the mean

${ }^{a, b}$ Means within the same column with different letters are significantly different $(\mathrm{P}<0.05)$ 
Table 10. Nutrient digestibility of a grower diet fed to Ross 308 broiler and Venda chickens aged 42 days

\begin{tabular}{c|c|c|c}
\hline Parameters & Ross 308 broiler & Venda chickens & SEM \\
\hline Digestibility (Decimal) & $0.83^{\mathrm{a}}$ & $0.56^{\mathrm{b}}$ & 0.030 \\
DM & $0.92^{\mathrm{a}}$ & $0.76^{\mathrm{b}}$ & 0.071 \\
CP & $15^{\mathrm{a}}$ & $10^{\mathrm{b}}$ & 0.263 \\
ME* $^{*}$ & $6^{\mathrm{a}}$ & $1^{\mathrm{b}}$ & 0.041 \\
\hline
\end{tabular}

DM: Dry matter

CP: Crude protein

ME: Metabolisable energy (MJ/kg DM)

SEM: Standard error of the mean

${ }^{\mathrm{a}, \mathrm{b}}$ Means within the same row with different letters are significantly different $(\mathrm{P}<0.05)$

\section{Discussion}

The blood parameters of chickens are regarded as dependable and good indicators of the bird's health status. Haematological indices are reported not to be consistent in chickens because of a number of reasons including diseases (Fudge, 2000b), stress (Bedonova et al., 2007), season (Hauptmanova et al., 2006) and genotype (Gayathri and Hegde et al., 2006). In the current study Ross 308 broiler and indigenous Venda chickens aged 42 days had similar haematological parameters. The values reported in the present study are within the normal ranges reported for Ross 308 broiler chickens aged 42 days by Tehrani et al. (2012) and Talebi et al. (2005). However, several studies conducted on indigenous chickens in other countries have reported contradicting haematological indices. Higher values of $\operatorname{WBC}\left(2.27-2.43 \times 10^{3} \mathrm{cell} / \mu \mathrm{L}\right)$ and $\mathrm{MCH}$ (66-70 pg) were observed in Nigerian local chickens (Peters et al., 2011) than the indigenous chickens in the current study. In the study by Pampori and Iqbal (2007), values of for HCT and $\mathrm{Hb}$ were higher in Kashmir native chickens than the values obtained in indigenous chickens in the present study. The platelets in the current study were higher in Ross 308 broiler than indigenous Venda chickens. The results were contrary to those reported by Maxwell et al. (1991) who showed lower thrombocyte (platelets) of Ross 308 broiler chickens at the age of 7 weeks. These cells help in the blood clotting process by promoting homeostasis (Paul et al., 2012) which, therefore, indicates that at 42 days of age in the current study the functioning of these cells were poor in Venda chickens as compared to Ross 308 broiler chickens.

At 90 days of age the WBC, RBC, HCT and MCV were higher for Ross 308 broiler than indigenous Venda chickens. Values in the current study were contrary described by Pampori and Iqbal (2007), Peters et al. (2011) and Albokhadiam et al. (2012) who found that indigenous chickens had higher haematological values or indices than broiler chickens. However, supporting the current findings is a report by El-Safty et al. (2006) which indicated that $\mathrm{WBC}$ and $\mathrm{MCH}$ were higher in broiler than indigenous chickens. The haemoglobin blood concentrations and platelets were higher for indigenous Venda chickens in the current study than Ross 308 broiler chickens. The higher haemoglobin values of indigenous Venda chickens in the present study are similar to those reported by Orawen and Aengwanich (2007) for indigenous chickens. However, MCH, MCHC and RDW were not influenced by breed in the present study. 
The serum parameters at the ages of 42 days were similar between the chicken breeds. However, the serum total protein was higher in indigenous Venda than in Ross 308 broiler chickens, the levels reported in the current study were still lower $(20 \mathrm{~g} / \mathrm{L}$ for Ross 308 and $25 \mathrm{~g} / \mathrm{L}$ for indigenous Venda chickens) than those reported (33-47g/L in Ross 308 broiler aged 42 days) in a study by Piotrowska et al. (2011). Total serum protein can extremely vary in chickens and its variation depends on internal and external factors and results from physiological roles in blood proteins. This parameter is important to measure the chickens' body condition. Other differences identified where serum creatinine was higher for Ross 308 broiler than indigenous Venda chickens at 42 and 90 days of age. Serum creatinine is an important indicator of protein metabolism, a by-product of phosphocreatine breakdown in skeletal muscles (Piotrowska et al., 2011). Its concentration is directly related to muscle mass and is associated with age and physical activity (Szabo et al., 2005; Rajman et al., 2006). The serum creatinine values for Naked neck and Kashmir indigenous chickens reported in the studies conducted by Peters et al. (2011) and Pampori and Iqbal (2007) were higher (13 and $14 \mu \mathrm{mol} / \mathrm{L}$, respectively) than values of indigenous Venda chickens in the current study at 42 days of age. Lipid metabolites are associated with energy metabolism and reflect fluctuations occurring during the growth period of chickens. At 42 days of age there were differences observed in the triglycerides concentration between the breeds. However, high triglycerides concentrations levels in indigenous Venda chickens were observed at 90 days of age.

Higher serum triglycerides concentrations, most often, represent intensive lipid metabolism and transport. These results are supported by Piotrowska et al. (2011) who indicated that the serum triglycerides of Ross 308 broiler chicken decrease as they grow in age. However, on the contrary Abdi-Hachesoo et al. (2011) indicated that no serum triglycerides difference was observed between Iranian indigenous and Ross 308 broiler chickens. Higher serum cholesterol levels were observed for Ross 308 broiler in the current study. These findings are similar to those reported by Abdi-Hachesoo et al. (2011) and Simaraks et al. (2004) who showed that serum cholesterol of indigenous chickens is lower than other breeds. The authors went further to hypothesize that this might be because of the high body activity and high energy need in the indigenous chickens.

Minerals are essential for chickens' growth and are involved in many biosynthetic processes in the body. Calcium is mainly needed for ossification of bones, regulation of muscle activity and catalyzation of enzyme and hormonal synthesis (Underwood and Suttle, 1999). On the $90^{\text {th }}$ day serum calcium was higher for Ross 308 broiler than indigenous Venda chickens. Abdi-Hachesoo et al. (2011) reported similar serum calcium values between Ross 308 broiler and Iranian indigenous chickens.

Differences in GIT weights and lengths between the two breeds used in the current study were observed. GIT were heavier and longer in Ross 308 broiler than indigenous Venda chickens. It was clearly evident in the present study that the slow growing indigenous Venda chickens abundant in rural South Africa and with lighter live and carcass weights, had inferior GIT weights and lengths. A study conducted by Borin et al. (2006) indicated that the GIT weights and lengths of indigenous chickens were heavier and longer compared to broiler chickens aged 120 days. The authors explained this by stating that due to the extensive traditional system these chickens are kept under the availability of bulky and fibrous feeds which will contribute to superior GIT weights and lengths than those of the fast growing broiler chickens. These findings are contrary 
to the current study. The current study is supported by Khempaka et al. (2009), De Verdal et al. (2010) and Mossammi et al. (2011) who indicated that GIT lengths and weights of broiler chickens are superior. A recent study by Mabelebele et al. (2014) conducted on indigenous Venda and broiler chickens noted that broiler chickens with their heavier body weight tended to have heavier and longer GIT and digestive organs, with the exception of the gizzard under an intensive system which supports the current findings.

The intestinal villus and crypt morphology are associated with intestine function and growth in chickens. According to Tivey and Smith (1989), changes in enterocytes development and villi structure determine the digestive and absorptive capacity of the small intestine. The small intestine histomorphology including villus height, crypt depth and their ratio are important pointers of gut health in chickens. Increased villus height and villus height to crypt depth ratio are directly correlated with an increased epithelial turnover and longer villi are associated with activated cell mitosis (Montangne et al., 2003). On the other hand, a decrease in villus to crypt ratio or lower crypt to villus ratio is indicative of a higher rate of enterocyte-cell migration from the crypt to the villus (Adibmoradi et al., 2006; Silva et al., 2009). This can lead to poor nutrient absorption, increased secretion in gastrointestinal tract and reduced performance. In the current study the villus height and crypt depth in the duodenum and ileum were higher for Ross 308 broiler than indigenous Venda chickens. The smallest depth of the crypts was observed from indigenous Venda chickens. Decreasing crypt depth in indigenous chickens might be explained by the fact that the crypt can be regarded as the villus factory and a large crypt indicates rapid tissue turnover and a high demand for new tissues (Choct, 2009). The increased villus height in the small intestines could be associated with higher absorptive intestinal surface (Loddi et al., 2004) which facilitates the nutrient absorption and hence, has a direct impact on growth performance. This indicates that Ross 308 broiler chickens with longer and heavier GIT had better absorptive functions and, therefore, growth as compared to indigenous Venda chickens. At 90 days of age, chickens had similar intestinal villus height. This, however, does not imply that the breeds had similar nutrient absorption potential as the crypt depths are different. Ross 308 broiler chickens had higher crypt depth which is indicative of a higher epithelial cell turn over to permit renewal of the villus as needed (Langhout et al., 1999; Sobayo et al., 2012). Thus, a better absorption potential is evidenced by Ross 308 broiler chickens compared to indigenous Venda chickens. The better intestinal and absorptive functions in Ross 308 broiler chickens, perhaps, can be best interpreted by higher nutrient digestibility and $\mathrm{N}$ retention as observed in the current study.

\section{Conclusion and Recommendations}

Age affects the blood profiles of both broiler and indigenous chickens. It was observed that at age 42 days, most haematological and biochemical parameters were similar between broiler and indigenous Venda chickens. However, platelets and serum creatinine were higher for Ross 308 broiler chickens at 42 days of age. At 90 days of age, WBC, RBC, Haematocrit, MCV, platelets, serum calcium, creatinine, cholesterol and albumen were higher for Ross 308 broiler chickens. Total protein at 42 days of age, platelets, haemoglobin, serum triglycerides at 90 days of age were higher for Venda chickens. It was expected that indigenous Venda chickens would have superior immunological abilities than broiler chickens in the current study. However, this was 
not the case, debunking the perception that indigenous chickens are hardier and more resistant to diseases than the broiler chickens. Perhaps the immunological abilities of indigenous chickens are superior when kept under extensive conditions, which was not the case in this study. A comparative study should be conducted on the blood profiles of indigenous chickens under intensive and extensive rearing systems.

Breed and age had an influence on the gastrointestinal tract lengths and weights. This was expected as broiler chickens have superior body weights with faster growth rate compared to indigenous chickens. The histology of the small intestine segments varied between breed and age. Higher villus height and deeper crypt depth were observed in Ross 308 broiler than indigenous chickens. This shows the better absorptive functions of the broiler chicken breed which in turn results to faster growth rate.

Acknowledgements. The authors would like to acknowledge and appreciate the funding from National Research Foundation (NRF), South Africa which made this work possible. Special gratitude to (National Health Laboratory Service) NHLS, Polokwane, manager Mr Lucas Kgwetiana for allowing us to use the lab facilities for analyses.

\section{REFERENCES}

[1] Abdi-Hachesoo, B., Talebi, A., Asri-Rezaei , S., Basaki, M. (2013): Sex related differences in biochemical and haematological parameters of adult indigenous chickens in north-west of Iran. - Journal of Animal Science Advances 3: 512-516

[2] Abdi-Hachesoo, B., Talebi, A., Asri-Rezaei, S. (2011): Comparative study on blood profiles of indigenous and Ross 308 broiler breeders. - Global Veterinaria 7: 238-241.

[3] Adibmoradi, M., Navidshad, B., Seifdavati, J., Royan, M. (2006): Effect of dietary garlic meal on histological structure of small intestine in broiler chickens. - Poultry Science 43: 378-383.

[4] Aitken, R. N. C. (1958): A histochemical study of the stomach and intestine of the chicken. - Journal of Anatomy 92(3): 453-466.

[5] Albokhadaim, I. (2012): Haematological and some biochemical values of indigenous chickens in al-ahsa, Saudi Arabia during summer season. - Asian Journal of Poultry Science 6: 138-145.

[6] Aravind, K. L., Patil, V. S., Devegowda, G., Umakantha B., Ganpule, S. P. (2003): Efficacy of esterified glucomannan to counteract mycotoxicosis in naturally contaminated feed on performance and serum biochemical and haematological parameters in broilers. Poultry Science 82: 571-576.

[7] Bedanova, I., Voslarova, E., Vecerek,V., Pistekova, V., Chloupek, P. (2007): Haematological profile of broiler chickens under acute stress due to shackling. - Journal of Acta Veterinaria Brno 76: 129-135.

[8] Borin, K., Lindberg, J. E., Ogie, R. B. (2006): Digestibility and digestive organ development in indigenous and improved chickens and ducks fed diets with increasing inclusion levels of cassava leaf meal. - Journal of Animal Physiology 90: 230-237.

[9] Calhoun, M. L. (1954): Microscopic anatomy of the digestive system of the chicken. Ames, Iowa: Iowa State Colleage Press.

[10] Carrijo, A. S., Wood, L. A. Sartori, J., Pezzato, A. C., Gill, J. C., Cruz, V. C., Kuibida, K., Pinheiro, D. F. (2005): Garlic powder in the alternative feeding broilers. - Brazilian Agricultural Research 40: 673-679.

[11] Choct, M. (2009): Managing gut health through nutrition. - British Poultry Science 7: 915. 
[12] De Verdal, H., Mignon-Grasteau, S.,Jeulin, C., Le Bihan-Duval, E., Leconte, M., Mallet, S., Martin, C., Narcy, A. (2010): Digestive tract measurements and histological adaptation in broiler lines divergently selected for digestive efficiency. - Poultry Science association 89: 1955-1961.

[13] El-Safty, S. A., Ali, U. M., Fathi, M. M. (2006): Immunological parameters and laying performance of naked neck and normally feathered genotypes of chickens under winter conditions of Egypt. - International Journal of Poultry Science 5: 780-785.

[14] Fudge, A. M. (2000b): Laboratory Medicine. Avian and exotic pets, ( $1^{\text {st }}$ Edition). Saunders.

[15] Gayathri, K. L., Hegde, S. N. (2006): Alteration in haematocrit values and plasma proteins fractions during the breeding cycle of female pigeons, Columba livia. - Animal Reproduction Science 91: 133-141.

[16] Hassouna, E. M. A. (2001): Some anatomical and morphometrical studies on the intestinal tract of chicken, duck, goose, turkey, pigeon, dove, quail, sparrow, heron, jackdaw, hoopoe, kestrel and owl. - Assiut Veterinary Medical Journal 44: 47-78.

[17] Hauptmanova, K, Maly, M., Literak, I. (2006): Changes in haematology in common pheasant throughout the year. - Veterinary Medicine 51: 29-34.

[18] Incharoen, T., Maneechote, P. (2013): The effects of dietary whole rice hull as insoluble fiber on the flock uniformity of pullets and on the egg performance and intestinal mucosa of laying hens. - American Journal of Agricultural and Biological Sciences 8: 323-329.

[19] Jamroz, D. (2005): Comparative characteristics of gastrointestinal tract development and digestibility of nutrients in young chickens, ducks and geese. - Proceedings of the $15^{\text {th }}$ European Symposium on Poultry Nutrition, September 25-29, 2005, Balatonfüred, Hungary, 74-85.

[20] Krás, R. V., Kessler, A. M., Ribeiro, A. M. L., Henn, J. D., Bockor, L., Sbrissia, A. F. (2013): Effect of dietary fibre, genetic strain and age on the digestive metabolism of broiler chickens. - Brazilian Journal of Poultry Science 15, 83-90.

[21] Langhout, D. J., Schutte, J. B., Van Leeuwen, P., Wiebenga, J., Tamminga, S. (1999): Effect of dietary high and low methyllated citrus pectin on the activity of the ileal microflora and morphology of the small intestinal wall of broiler chickens. - British Poultry Science 40: 340-347.

[22] Loddi, M. M., Maraes, V. M. B., Nakaghi, I. S. O., Tucci, F., Hannas, M. I. Ariki, J. A. (2004): Mannan oligosaccharide and organic acids on performance and intestinal morphometric characteristics of broiler chickens. - Proc. $20^{\text {th }}$ Annu. Symp. Comp. Geom., Brooklyn, NY., 45.

[23] Mabelebele, M., Alabi, O.J, Ng`ambi, J. W., Norris, D., Ginindza, M. M. (2014): Comparison of gastrointestinal tracts and $\mathrm{pH}$ values of digestive organs of Ross 308 broiler and indigenous Venda chickens fed the same diet. - Asian Journal of Animal and Veterinary Advances 9: 71-76.

[24] Montagne, L., Pluske, J. R., Hampson D. J. (2003): A review of interactions between dietary fibre and the intestinal mucosa and their consequences on digestive health in young non-ruminant animals. - Animal Feed Science and Technology 108: 95-117.

[25] Orawan, C., Aengwanich, W. (2007): Blood cell characteristics, haematological values and average daily gained weight of Thai indigenous, Thai indigenous crossbred and broiler chickens. - Pakistan Journal of Biological Sciences 10: 302-309.

[26] Pampori, Z. A., Saleem, I. (2007): Haematology, serum chemistry and electrocardiographic evaluation in native chicken of Kashmir. - International Journal of Poultry Science 6: 578-582.

[27] Paul, M. S., Paolucci, S., Barjesteh, N., Wood, R. D., Schat, K. A., Sharif, S. (2012): Characterization of Chicken Thrombocyte Responses to Toll-Like Receptor Ligands. PLoS One 7: e43381.

[28] Pauwels, J., Coopman, F., Cools, A., Michiels, J., Fremaut, D., De Smet, S., Janssens, G. P. J. (2015). Selection for Growth Performance in Broiler Chickens Associates with Less 
Diet Flexibility. - PLoS ONE 10(6): e0127819.

http://doi.org/10.1371/journal.pone.0127819

[29] Peters, S. O., Gunn, H. H., Imumorin, I. G., Agaviezor, B. O., Ikeobi, C. O. N. (2011):

Haematological studies on frizzled and naked neck genotypes of Nigerian native chickens. - Tropical Animal Health and Production 43: 631-638.

[30] Piotrowska, A., Burlikowska, K., Szymeczko, R. (2011): Changes in blood chemistry in broiler chickens during the fattening period. - Folia biologica (Kraków) 59: 183-187.

[31] Ritchie, B. W., Harrison, J. G., Harrison, J. L. (1994): Avian Medicine. Principle and Application. - Winger's Publishing, Inc, Lake Worth, Florida, USA.

[32] Samanya, M., Yamauchi, K. E. (2002): Histological alterations of intestinal villi in chickens fed dried Bacillus subtilis var.natto. - Comparative Biochemistry and Physiology Part A: Molecular and Integrative Physiology 133: 95-104.

[33] SAS. (2008): Statistical Analysis System. User's Guide: Statistics, $11^{\text {th }}$ Edition. - SAS Institute, Inc. Raleigh, North Caroline, USA.

[34] Silva, M. A., Pessotti, B. M. S., Zanini, S. F., Colnago, G. L., Rodrigues, M. R. A., Nunes, L. C., Zanini, M. S., Martins, I. V. F. (2009): Intestinal mucosa structure of broiler chickens infected experimentally with Eimeria tenella and treated with essential oil of oregano. - Revista do Centro de Ciências Rurais 5, 1471-1477.

[35] Simaraks, S., Chinrasri, O., Aengwanich, W. (2004): Haematological, electrolyte and serum biochemistry values of the Thai indigenous chickens (Gallus domesticus) in northeastern Thailand. - Songklanakarin Journal of Science and Technology 26: 425-430.

[36] Sobayo, R. A., Oso, A. O., Adeyemi, O. A., Fafiolu, A. O,. Jegede, A. V., Idowu, O. M. O., Dairo, O. U., Iyerimah, R. B., Ayoola, O. A., Awosanya, R. A. (2012): Changes in growth, digestibility and gut anatomy by broilers fed diets containing ethanol-treated castor oil seed (Ricinus communis L.) meal. - Revista Científica UDO Agrícola 12: 660-667.

[37] Szabo, M.P.J., Mangold, A.J., Carolina, J.F., Bechara, G.H., Guglielmone, A.A. (2005): Biological and DNA evidence of two dissimilar populations of the Rhipicephalus sanguineus tick group (Acari: Ixodidae) in South America. - Veterinary Parasitology 130: 131-140.

[38] Talebi, A., Asri-Rezaei, S., Roszah-Chai, R, Sahraei, R. (2005): Comparative studies on haematological values of broiler strains (Ross, Cobbs, Arbor acres and Arian).International Journal of Poultry Science 4: 573-579.

[39] Tivey, D. R., Smith, M. W. (1989): Cytochemical analysis of single villus peptidase activities in pig intestine during neonatal development. - Histochemical Journal 21: 601-608.

[40] Underwood, E. J., Suttle, N. F. (1999): The Mineral Nutrition of Livestock. 3rd Ed. CABI Publishing, CAB International, Wallingford, Oxon, UK, pp. 614. 